\title{
ENTREPRENEURIAL INTENTIONS OF YOUNG EDUCATED PUBLIC IN TURKEY
}

\author{
Gulruh GURBUZ \\ Sinem AYKOL \\ Marmara University, Turkey
}

\begin{abstract}
The main objective of this study is to analyze the factors that determine the entrepreneurial intention of young educated public in Turkey. The model of our study includes the effects of demographics, contextual factors and the components of Theory of Planned Behaviour (TPB) on the entrepreneurial intention of the individuals. Based on the model a questionnaire was developed and distributed to 324 students of a state university in Istanbul. The results showed that gender, having entrepreneurial parents, subjective norm, perceived behavioral control; attitudes, favorable environmental conditions, and academic support were the determinants of entrepreneurial intention.
\end{abstract}

\section{INTRODUCTION}

Today knowledge and globalization are the forces that drive the national economies of the countries in the world. In order to keep up with these challenges, creativity, innovation, and flexibility have to be promoted. This implies that the economies have to be entrepreneurial. The entrepreneurial economies can be created through individual entrepreneurs and the firms they establish (Sariaslan, 2001).

Entrepreneur is the person who establishes his/her own firm (Gartner, 1988).Entrepreneurs play a key role in creating jobs , promoting innovation, creating economic wealth, and thus increasing the general health and welfare of the economy (Morrison, Breen and Ali, 2003; Poutziouris, 2003). Therefore, entrepreneurs are crucial for national and regional economic development (Sadler-Smith, Hampson, Chaston and Badger, 2003).

In that sense entrepreneurship is a strategic issue and it has to be analyzed at macro level. When governments realize the importance of entrepreneurs for the economic development of the nation, they can include entrepreneurial issues in their national economic development plans. Entrepreneurship can be supported through nation wide. Entrepreneurial issues can even take its place in the education policy of the nation. Factors that lead the individuals to become entrepreneurs in that country can thoroughly be investigated so necessary adjustments can be done in the higher education system to foster the entrepreneurial intention of the youth in that country.

Consequently, academic research on different aspects of entrepreneurship is on the rise (Davidsson, 
1995).Although entrepreneurial intention is an important field in entrepreneurship, the reasons and determinants of entrepreneurial intention still lacks empirical evidence (Choo and Wong, 2006; Davidsson, 1995). In order to fill this gap, this study aims to shed light on the antecedents of entrepreneurial intention among young educated public in Turkey.

\section{ENTREPRENEURIAL INTENTION}

"Entrepreneurial intention" is one's willingness in undertaking entrepreneurial activity, or in other words become self employed. The opposition of selfemployment is becoming a waged or salaried individual (Tkachev and Kolvereid, 1999). From this perspective, measuring entrepreneurial intentions may be regarded as measuring latent entrepreneurship (Verheul, Thurik and Grilo, 2005).

In literature several factors that influence the willingness to take entrepreneurial activity have been noted (Kolvereid, 1996; Verheul et al., 2005). Demographic factors such as age and gender have been proposed to have an impact on entrepreneurial intention (Kristiansen and Indarti, 2004). In literature, it is argued that females are less likely to establish their own business than men (Phan, Wong, and Wang, 2002; Verheul, et al, 2005). Age can be an important factor in entrepreneurial intention. Research shows that people mostly decide to establish their won firms between the ages of 25 to 45 years old (Storey, 1994).

This tendency increases especially between the ages of 25 to 34 (Delmar and Davidsson, 2000). In addition, empirical studies also focused on individual background characteristics such as education, prior employment experience and parental role models to explain entrepreneurial intention (Kristiansen and Indarti, 2004). There are contradictory findings on educational level and entrepreneurial activity. Some argue that education have a positive impact on self employment (Bates, 1995) whereas others find a negative relationship and disagree with his proposition (Reynolds, 1995). It can be argued that for people with lower educational levels, self-employment can be the only option. In other words, their probability of getting into an organization as a waged salary is low. On the other hand, people with higher education have better chances for success both as an entrepreneurs and a waged employee (Davidsson, 1995). Entrepreneurial experience in other words previous ownership is the number of involvements and role of the entrepreneur in new venture creation (Lee and Tsang, 2001). This type of experience is also expected to have a positive impact on entrepreneurial intentions
(Phan et al., 2002; Tkachev and Kolvereid, 1999). Involving in the establishment of different firms will provide the entrepreneur the opportunity of knowing the risks and problems associated with new venture formation (Barringer, Jones and Neubaum, 2005; Welter, 2001). Role models are important factors in the determination of career choices. Role modeling refers to learning by examples rather than direct experience. In role modeling, the individual adopts the behavior by informal and unintentional observation (Tkachev and Kolvereid, 1999). Especially role models in the family setting are considered as the most influential factor in the career choices of people. Having entrepreneurial parents is considered to be an important factor for entrepreneurial intentions. Entrepreneurial parents form a role model and create management know-how for the individual entrepreneur (Papadaki and Chami, 2002). The children of entrepreneurs learn the factors involved in running a business and consider establishing a new organization as a natural career option (Cooper, Gimeno-Gascon, and Woo, 1994; Papadaki and Chami, 2002; Sandberg and Hofer, 1987).

Another field of research that focused on entrepreneurship and entrepreneurial intention is personality traits (Kristiansen and Indarti, 2004). The aim of this personality approach is to identify a group of traits that can differentiate entrepreneurs from nonentrepreneurs. The main assumption of this approach is that people who choose self-employment as a career option have a different personality profile than people who prefer organizational employment (Kolvereid, 1996). Need for achievement, locus of control and risk taking propensity can be examples of most commonly studied personality traits of entrepreneurial behavior (Phan et al., 2002). These personality traits are usually associated with entrepreneurial behavior (Begley and Boyd, 1987; Hornaday and Aboud, 1971; Lee and Tsang, 2001). According to this view, the entrepreneurs are expected to have higher levels of need for achievement, internal locus of control and risk taking propensity. Although personality traits are widely used in the explanation for entrepreneurial behavior, this approach is often criticized for having small explanatory power, predictive validity and moreover inconsistent findings across studies. In short, this approach did not lead to satisfactory results in explaining entrepreneurship (Krueger et al., 2000; dePillis and Reardon, 2007).

Recent studies propose that intentions influence the behavior. In other words, actual behavior is determined by intentions (Ajzen, 1991). There are two similar and dominants models in this approach: Shapero's 
"entrepreneurial event" (SEE) model and Ajzen's theory of planned behavior (TPB) (Guerrero et al., 2008). Shapero's SEE model argues that potential entrepreneurs have to consider entrepreneurship as a "credible" career alternative. This "credibility" occurs when the potential entrepreneur perceives the venture as both desirable and favorable (Kolvereid, 1997). TPB also aims to explain how intentions can predict actual behavior. This is a commonly used theory that aims to explain and predict why people behave in certain ways. The TPB proposes three main reasons for intention. The first one is the appraisal of the behavior, which is the extent to which a person has favorable or unfavorable attitude towards behavior. The second determinant is the subjective norm that is the social pressure to perform the behavior. The perceived difficulty to perform the behavior is called perceived behavioral control which is the third element for intention (Ajzen, 1991; Kolvereid, 1997; Tkachev and Kolvereid, 1999). According to this theory, in order to increase a person's intention to perform a behavior, the attitude and subjective norm towards that behavior has to be more favorable and the perceived behavior control has to be greater (Kolvereid, 1997). Although these are two separate theories of intention, they have overlapping notions. For instance, they are both linked to perceived self-efficacy. Perceived behavioral control in TPB is similar to perceived feasibility in (SEE) model. In addition, SEE) model's perceived desirability covers subjective norm and attitude dimension of TPB (Kolvereid, 1997; Krueger and Brazeal, 1994).

In literature, contextual elements are also included in the studies of entrepreneurial intention. Contextual elements are the environmental factors that might have an impact on entrepreneurial intention. Economic, political and cultural climate, administrative complexities, having access to resources, and physical and institutional infrastructure can be regarded as environmental factors (Kristiansen and Indarti, 2004; Verheul, et al., 2005). Administrative complexities refer to the degree of administrative complication in establishing a business. These activities can be very time consuming and expensive which eventually discourage acts of entrepreneurship. Access to information is an important element for the intention to establish a new business (Kristiansen and Indarti, 2004). Having access to business information is the availability of information in the environment about establishing a new venture and how to run a business. Access to finance is the ability of the individual to find financial support to establish a business since most of the investors and banks are not willing to make investments in new ventures. Availability of capital is regarded as one of the common obstacles to establish a new business by potential entrepreneurs (Kristiansen and Indarti, 2004). General economic climate is the availability of entrepreneurial opportunities and risks associated with them (Verheul, et al, 2005).In studies of entrepreneurial intention, it is recommended to study environment at the perceptional level because rather than the actual environment the perceptions of the individual are important for determining the opportunities and resources in the environment. According to his/her perceptions about the environment, one can determine whether to undertake entrepreneurial activities or not. Therefore measuring the actual environment may not be relevant in studies of occupational choices; in this case self employment (Kristiansen and Indarti, 2004; Verheul et al, 2005).

Based on the literature review, our proposed research model is as follows:

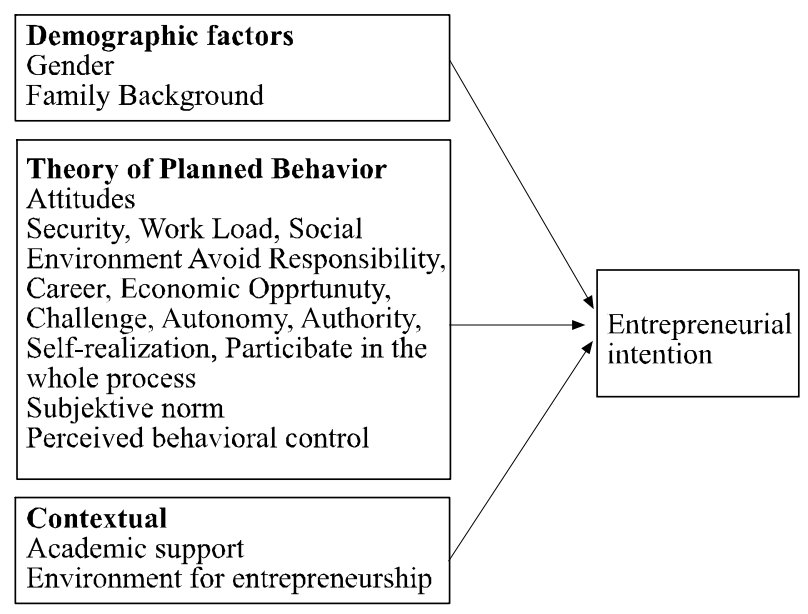

\section{Figure 1: Proposed Research Model}

Based on the proposed research model, the following hypotheses are developed for empirical analyses.

H1. Demographic factors as gender and family background have an influence on entrepreneurial intention.

H2. Attitudes have an impact on entrepreneurial intention.

H3. Subjective Norm has an impact on entrepreneurial intention.

H4. Perceived behavioral control has an impact on entrepreneurial intention.

H5: Contextual elements as academic support and environment for entrepreneurship are significant predictors of entrepreneurial intention. 


\section{METHODOLOGY}

\section{Survey Instrument}

As a research instrument, a structured survey was used because it provides the researchers the opportunity to gather data about variety of factors and reach a larger sample. Questionnaire is composed of 4 parts which are TPB, demographic factors, contextual elements and entrepreneurial intention. The questionnaire has 46 items in total.

TPB index is composed of 3 parts; occupational status choice attitude index, subjective norm and perceived behavioral control. In this study, Kolvereied (1996)'s occupational status choice attitude index was used. This index has its origins from the TPB and aims to measure the attitude towards self-employment. This index includes five motives for choosing organizational employment and six motives for becoming selfemployment. The scale has a total of 33 items. The scale was composed of statements related to the security, work load, social environment, avoid responsibility, career, economic opportunity, challenge, autonomy, authority, self realization and participate in the whole process. The participants were asked to indicate their degree of agreement with these statements on a six-point scale ranging from "strongly disagree" $=1$ to "strongly agree" $=6$. The items measuring subjective norm were taken from by Kolvereid (1996) and one item was added from the study of Autio, Keeley, Klofsten, Parker and Hay (2001). The four items aimed to measure the belief of the participant about the social support $\mathrm{s} /$ he will get if $\mathrm{s} / \mathrm{he}$ pursues a career as selfemployed. For example the first question was "If I became an entrepreneur, my family would consider it to be good". The participants were asked to indicate their degree of agreement with these four statements on a six-point scale ranging from "strongly disagree" $=1$ to "strongly agree" $=6$. Motivation to comply was measured by four items referring to each of the belief questions. An example for motivation to comply is "To what extent do you care about what your closest family think when you are to decide whether or not to pursue a career as elf-employed?" The participants were asked to indicate their degree of agreement with these four statements on a six-point scale ranging from "do not care at all"=1 to "I care very much" $=6$. The belief items were re-coded into a bipolar scale then multiplied with the respective motivation to comply item and finally the scores added in order to obtain an overall measure of subjective norm (Cronbach's $?=0.81$ ).In order to measure perceived behavioral control 6-item measure developed from Kolvereid (1996) and Autio et al. (2001). The participants were asked to indicate their degree of agreement with these statements on a six-point scale ranging from "strongly disagree" $=1$ to "strongly agree" $=6$. The contextual elements had two components; academic support and environmental factors. The academic factors were adopted from Autio et al. (2001). The environmental factors were taken form the study of Verheul et al., 2005). This scale had 8 questions in total. The respondents were asked to rate their degree of agreement with items on a six-point scale ranging from "strongly disagree" $=1$ to "strongly agree" $=6$. In this study gender and family background are taken as indicators of entrepreneurial intention. In this study the entrepreneurial intention which is the ultimate dependent variable is measured by the index of Davidsson (1995). Davidsson (1995) measured entrepreneurial intention on an index of three questions: (1) 'Have you ever considered founding your own firm?'; and (2-3) 'How likely do you consider it to be that within one (or five) years from now you'll be running your own firm?' The respondents were asked to rate their degree of agreement with items on a sixpoint scale ranging from "strongly disagree" $=1$ to "strongly agree" $=6$. The construct was thus based on these three statements. The Cronbach Alpha for this construct was 0.75 .

\section{Study Sample}

University students were our unit of analysis. Data were collected from 324 3rd and 4th year university students of Faculty of Economics and Administrative Sciences and Engineering Faculty of a state university in Istanbul. 3rd and 4th year university students were chosen because they are at the stage of making career choices.

\section{Findings}

In this study, the collected data was initially analyzed by reliability and factor analysis. The relationships between dependent and independent variables were tested by multiple regression analysis.

Reliability and Factor Analysis of Occupational Status Choice Attitude Index

After the first factor analysis, 2 factors emerged. One item with a factor loading lower than 0.50 was eliminated. Factor analysis was run again and again resulted in 2 factors. The findings of this analysis can be found in Table 1. 
Table 1. Reliability and Factor Analysis of Occupational Status Choice Attitude Index

\begin{tabular}{|c|c|c|c|c|}
\hline Factor & $\begin{array}{l}\text { Variance } \\
\text { loadings }\end{array}$ & $\begin{array}{l}\text { Cronbach } \\
\text { Explained }\end{array}$ & $\begin{array}{r}\text { Number } \\
\text { alpha }\end{array}$ & of items \\
\hline Autonomy and Authority & & 16.026 & 0.923 & 6 \\
\hline Have power to make decisions & 0.838 & & & \\
\hline Have authority & 0.794 & & & \\
\hline Be able to choose your own tasks & 0.768 & & & \\
\hline To be your own boss & 0.757 & & & \\
\hline Independence & 0.742 & & & \\
\hline Freedom & 0.689 & & & \\
\hline Economic Opportunity and Challenge & & 14.950 & 0.907 & 8 \\
\hline To have a challenging job & 0.749 & & & \\
\hline To have an exciting job & 0.728 & & & \\
\hline To have a motivating job & 0.697 & & & \\
\hline To receive compensation based on merit & 0.696 & & & \\
\hline To have an interesting job & 0.633 & & & \\
\hline To keep a large proportion of the result & 0.632 & & & \\
\hline Economic opportunity & 0.630 & & & \\
\hline Self realization & 0.535 & & & \\
\hline Security and Work Load & & 10.102 & 0.799 & 5 \\
\hline Job stability & 0.777 & & & \\
\hline Job security & 0.753 & & & \\
\hline Not having to work long hours & 0.750 & & & \\
\hline To have fixed working hours & 0.735 & & & \\
\hline Not to have a stressful job & 0.526 & & & \\
\hline Avoid Responsibility & & 9.748 & 0.819 & 4 \\
\hline Not taking on too much responsibility & 0.886 & & & \\
\hline Avoid responsibility & 0.872 & & & \\
\hline Avoid commitment & 0.746 & & & \\
\hline Have a simple, not complicated job & 0.695 & & & \\
\hline Self realization and Participation & & 9.538 & 0.819 & 4 \\
\hline To create something & 0.727 & & & \\
\hline To take advantage of your creative needs & 0.712 & & & \\
\hline To follow work tasks from a to $\mathrm{z}$ & 0.664 & & & \\
\hline Participate in the whole process & 0.603 & & & \\
\hline Social Environment and career & & 8.473 & 0.824 & 4 \\
\hline Participate in a social environment & 0.842 & & & \\
\hline To be a member of a social "milieu" & 0.789 & & & \\
\hline Have opportunity for career progress & 0.705 & & & \\
\hline Promotion & 0.696 & & & \\
\hline Total Variance Explained & & 68.838 & 0.917 & 31 \\
\hline $\begin{array}{l}\text { Kaiser-Meyer-Olkin Measure of Sampling } \\
\text { Adequacy. }\end{array}$ & 0.876 & & & \\
\hline $\begin{array}{r}\text { Bartlett's Test of Sphericity } \\
\text { App. Chi-Square } \\
\text { df } \\
\text { Sig. }\end{array}$ & $\begin{array}{r}5658.109 \\
465 \\
0.000\end{array}$ & & & \\
\hline
\end{tabular}

\section{Reliability and Factor Analysis of Perceived Behavioral Control Index}

The perceived behavioral control index resulted in two factors after the first factor analysis. One item was eliminated due to low factor loadings. When the factor analysis was run again, tow factors emerged. As seen in Table 2, they were labeled as "perceived confidence" and "perceived behavioral control". 
Table 2. Reliability and Factor Analysis of Perceived Behavioral Control Index

\begin{tabular}{|l|r|r|r|r|}
\hline & $\begin{array}{r}\text { Factor } \\
\text { loadings }\end{array}$ & $\begin{array}{r}\text { Variance } \\
\text { Explained }\end{array}$ & $\begin{array}{r}\text { Cronbach } \\
\text { alpha }\end{array}$ & $\begin{array}{r}\text { Number } \\
\text { of items }\end{array}$ \\
\hline Perceived Confidence & & $\mathbf{3 8 . 4 3 3}$ & $\mathbf{0 . 7 5 9}$ & $\mathbf{3}$ \\
\hline $\begin{array}{l}\text { I am confident that I would succeed if I } \\
\text { started my own firm. }\end{array}$ & 0.913 & & & \\
\hline $\begin{array}{l}\text { I have the capabilities skills required to } \\
\text { succeed as an entrepreneur. }\end{array}$ & 0.854 & & & \\
\hline I have the skills required to succeed as an entrepreneur. & 0.567 & & & \\
\hline Perceived Behavioral Control & & $\mathbf{3 2 . 7 5 7}$ & $\mathbf{0 . 6 0 0}$ & \\
\hline It would be easy for me to start my own firm. & 0.833 & & & \\
\hline $\begin{array}{l}\text { To start my own firm would probably be the best } \\
\text { way for me to take advantage of my education. }\end{array}$ & 0.811 & & & \\
\hline Total Variance Explained & & 71.190 & 0.736 & \\
\hline Kaiser-Meyer-Olkin Measure of Sampling Adequacy. & 0.678 & & & \\
\hline $\begin{array}{c}\text { Bartlett's Test of Sphericity App. Chi-Square } \\
\text { df }\end{array}$ & 387.101 \\
Sig. & 0.000 & & & \\
\hline
\end{tabular}

Reliability and Factor Analysis of Academic Support

The 4 items measuring academic support were loaded on a single factor which was labeled "academic support" with Cronbach's $\alpha=0.783$.

Table 3.Reliability Analysis of Academic Support Scale

\begin{tabular}{|l|r|r|}
\hline & $\begin{array}{r}\text { Cronbach } \\
\text { alpha }\end{array}$ & $\begin{array}{r}\text { Number } \\
\text { of items }\end{array}$ \\
\hline Academic Support & 0.783 & 4 \\
\hline $\begin{array}{l}\text { I know many people in my university who have } \\
\text { successfully started up their own firm. }\end{array}$ & & \\
\hline In my university, people are actively encouraged to pursue their own ideas. & & \\
\hline $\begin{array}{l}\text { In my university, you get to meet lots of people } \\
\text { with good ideas for a new firm. }\end{array}$ & & \\
\hline $\begin{array}{l}\text { There is a well functioning support infrastructure in } \\
\text { place to support the start-up of new firms. }\end{array}$ & & \\
\hline
\end{tabular}

Reliability and Factor Analysis of Environment for Entrepreneurship

The 4 items measuring environment for entrepreneurship were loaded on a single factor which was labeled as environment for entrepreneurship (Cronbach's $\alpha=0.739$ ).

Table 4.Reliability Analysis of Environment for Entrepreneurship

\begin{tabular}{|l|r|r|}
\hline & $\begin{array}{r}\text { Cronbach } \\
\text { alpha }\end{array}$ & $\begin{array}{r}\text { Number } \\
\text { of items }\end{array}$ \\
\hline Environment for Entrepreneurship & 0.739 & 4 \\
\hline $\begin{array}{l}\text { It is difficult to start one's own business due to } \\
\text { a lack of available financial support. }\end{array}$ & & \\
\hline $\begin{array}{l}\text { It is difficult to start one's own business due to } \\
\text { the complex administrative procedure }\end{array}$ & & \\
\hline It is difficult to obtain sufficient information on how to start a business. & & \\
\hline $\begin{array}{l}\text { The current economic climate is not favorable for people } \\
\text { who want to start their own business. }\end{array}$ & & \\
\hline
\end{tabular}

Multiple Regression Results for TPB on Entrepreneurial Intention 
Among the components of TPB, only five significant results were obtained $\left(\mathrm{R}^{2}=0.317, \mathrm{~F}=16.061, \mathrm{p}=0.000\right)$. Economic opportunity and challenge has a positive and the highest contribution to entrepreneurial intention $(\beta=0.405)$. Security and work load has a negative contribution to entrepreneurial intention with $\beta=-0.248$. Self realization and participation in the whole process also has a significant but negative contribution to entrepreneurial intention $(\beta=-0.169$ ). According to these findings, $\mathrm{H} 3$ is accepted. However, $\mathrm{H} 2$ and $\mathrm{H} 4$ are partially accepted.

\section{Table 5. Multiple Regression Significant Results for TPB on Entrepreneurial Intention}

\begin{tabular}{|l|r|l|l|}
\hline Independent Variables & \multicolumn{2}{|c|}{ Dependent Variable } \\
\hline & $\beta$ coefficients & & \\
\cline { 1 - 1 } Perceived Behavioral Control & 0.324 & & $\mathrm{R}^{2}=0.317$ \\
Economic Opportunity and challenge & 0.405 & Entrepreneurial & $\mathrm{F}=16.061$ \\
\cline { 1 - 1 } Security and Work Load & -0.248 & Intention & $\mathrm{p}=0.000$ \\
\cline { 1 - 1 } Self realization and participation in the whole process & -0.169 & & \\
\cline { 1 - 2 } Subjective Norm & 0.141 & & \\
\hline
\end{tabular}

Multiple Regression Results for Contextual Elements and Entrepreneurial Intention

Contextual elements have positive and significant contributions to entrepreneurial intention $\left(R^{2}=0.137 \mathrm{~F}=20.005\right.$ $\mathrm{p}=0.000$ ). Environment for entrepreneurship has a positive and the highest contribution to EO which means that entrepreneurial intention increase if one perceives the environment for entrepreneurship as supportive $(\beta=0.342)$. Academic support also had a positive contribution to entrepreneurial intention with $\beta=0.173$. H5 is accepted.

\section{Table 6. Multiple Regression Significant Results for Contextual Elements on Entrepreneurial Intention}

\begin{tabular}{|l|l|l|l|}
\hline \multicolumn{2}{|l|}{ Independent Variables } & Dependent Variable & \\
\cline { 1 - 2 } & $\beta$ coefficients & \multirow{2}{*}{$\begin{array}{l}\text { Entrepreneurial } \\
\text { Environment for entrepreneurship }\end{array}$} & $\begin{array}{l}\mathrm{R}^{2}=0.1372 \\
\mathrm{p}=0.000\end{array}$ \\
\cline { 1 - 2 } Academic support & 0.173 & Intention & 20.005 \\
\hline
\end{tabular}

\section{Multiple Regression Results for Demographic Factors and Entrepreneurial Intention}

In order to analyze gender and family back ground with regression analyses, they had to be recoded. In gender, females were recoded as 0 and males were recoded as 1 . For family background, respondents with entrepreneurial families were recoded as 1 and no entrepreneurial family history was recoded as 0 . The results of the regression analysis show that gender and family background are significant contributors to entrepreneurial intention $\left(\mathrm{R}^{2}=0.150 \mathrm{~F}=19.650 \mathrm{p}=0.000\right)$. Therefore, $\mathrm{H} 1$ is accepted according to the results of this study.

Table 7. Multiple Regression Significant Results for Demographic Factors on Entrepreneurial Intention

\begin{tabular}{|c|c|c|c|}
\hline \multicolumn{2}{|c|}{ Independent Variables } & Dependent Variable & \\
\hline & $\beta$ coefficients & \multirow{3}{*}{$\begin{array}{l}\text { Entrepreneurial } \\
\text { Intention }\end{array}$} & \multirow{3}{*}{$\begin{array}{l}\mathrm{R}^{2}=0.150 \mathrm{~F}=19.650 \\
\mathrm{p}=0.000\end{array}$} \\
\hline Gender & 0.341 & & \\
\hline Family Background & 0.170 & & \\
\hline
\end{tabular}




\section{RESULTS AND IMPLICATIONS}

In accordance with literature, the findings of this study showed that demographics, attitudes, and contextual factors were important for self-employment intentions of university students.

The multiple regression analysis results showed that gender and having entrepreneurial parents had significant and positive contributions to entrepreneurial intention. This finding is consistent with the entrepreneurial intention literature (Guerrero et al., 2008). The multiple regression analysis results for TPB revealed that perceived behavioral control, subjective norm and economic opportunity and challenge had positive contributions to entrepreneurial intention. In addition, security and workload had significant but negative contribution to entrepreneurial intention. This means that students prefer to become waged or salaried employees because of job security and work load. These findings are also in line with the previous studies which emphasize the importance of such factors in motivating would-be entrepreneurs (Choo and Wong, 2006).

TPB is a well-established predictor of entrepreneurial intention (Guerrero et al., 2008). An interesting finding of this study was; self realization and participation contributed negatively to self-employment intention. This contradicts with the entrepreneurship literature because people are expected to establish their own business in order to accomplish self-realization and participate in the whole work process (Choo and Wong, 2006). But for the Turkish university students working as a waged employee in a firm was regarded as a better approach in order to accomplish self realization and participation. This contrary finding to the literature may be due to the fact that Turkey is a developing country. The researches in literature is conducted in developed nations in which establishing a business and finding a job as a waged employee is easier when compared to Turkey. In Turkey, if the dream of the entrepreneur collapses when the established company is unsuccessful, it may be difficult for her/him to find a new job in a company. For that reason, Turkish people may prefer to stay in safer grounds working as waged employees in organizations.

In addition contextual elements also revealed significant and positive results with entrepreneurial intention. Favorable environment for entrepreneurship and academic support also affected the individual's entrepreneurial intention to establish his/her own

\section{business}

This study has also several implications for researchers, universities, and policy makers. For researchers, the application of these scales in a different cultural setting has some important implications. After factor analysis, factors our scales grouped differently than the original scales. In addition, one dimension of attitude, which is self-realization and participation, revealed negative results with entrepreneurial intention. Therefore, some dimensions of these concepts have to be redefined in different cultures.

It is important to understand the would-be entrepreneurs. If these characteristics and problems are identified, then the universities, government and other interested parties could develop programs that turn these latent entrepreneurs into nascent entrepreneurs (Phan et al., 2002; Verheul et al., 2005). In order to foster entrepreneurship, it is necessary to understand and find ways to develop and encourage latent entrepreneurs when they are still students (Wang and Wong, 2004). University students are in fact an important source for entrepreneurship. Their perceptions about entrepreneurship and establishing their own business will affect their career choices. Especially universities and educational institutions should develop programs that facilitate entrepreneurship so that more university graduates will be encouraged to establish their own businesses in the future (Wang and Wong, 2004).

It is widely believed that entrepreneurship and small firms are the major solutions to unemployment and economic development problems (Davidsson, 1995). In order to promote entrepreneurship in an economy, the policy makers have to focus on the ways to encourage entrepreneurship among well-educated university students and graduates (Wang and Wong, 2004). 


\section{REFERENCES}

Autio, E., Keeley, R., Klofsten, M., Parker, G., \& Hay, M. (2001), Entrepreneurial intent among students in

Scandinavia and in the USA, Enterprise and Innovation Management Studies, 2(2), 145-160.

Ajzen, I. (1991), The Theory of Planned Behaviour, Organizational Behaviour and Human Decision Processes, 50, pp. 179-211.

Barringer, B.R, Jones, F.F. and Neubaum, D.O. (2005), A Quantitative Content Analysis of the Characteristics of Rapid-Growth Firms and Their Founders, Journal of Business Venturing, Vol.20, No. 5, 663-687.

Bates, T., (1995), Self-employment entry across industry groups, Journal of Business Venturing 10, 143-156.

Begley, T.M. and Boyd, D.P. (1987), Psychological Characteristics Associated with Performance in Entrepreneurial Firms and Smaller Businesses, Journal of Business Venturing, Vol. 2, No. 1, 79-93.

Choo, Stephen and Wong Melvin,(2006),

Entrepreneurial intention: triggers and barriers to new venture creations in Singapore. Singapore Management Review, Vol.28 i2 ,pp47-64.

Cooper, A.C., Gimeno-Gascon, F.J. and Woo, C.Y. (1994), Initial human and financial capital as predictors of new venture performance, Journal of Business Venturing, Vol. 9, No. 5, 371-395.

Davidsson, P. (1995) Determinants Of Entrepreneurial Intentions, RENT IX Workshop in Entrepreneurship Research, Piacenza, Italy, 23-24 November.

Davidsson P., Kirchhoff, B., Hatemi-J, A. and Gustavsson, H. (2002), Empirical Analysis of Business Growth Factors Using Swedish Data, Journal of Small Business Management, Vol. 40, No. 4, pp.332-349.

DePillis, E. and Reardon, KK. (2007), "The influence of personality traits and persuasive messages on entrepreneurial intention", Career Development International, 12, 4, 382-396

Gartner, W. B. (1988), 'Who is an entrepreneur?' is the wrong question, American Small Business Journal, 12(4), pp. 11-31.

Guerrero M, Rialp J. and Urbano D., (2008), The impact of desirability and feasibility on entrepreneurial intentions: A structural equation model, International Entrepreneurship and Management Journal, 4 (1) pp. 35-50.
Hornaday, J.A. and Aboud, J. (1971), Characteristics of Successful Entrepreneurs, Personnel Psychology, Vol. 24, No. 2, 141-153.

Kristiansen, S. and Nurul I. (2004), Entrepreneurial Intentions among Indonesian and Norwegian Students, Journal of Enterprising Culture, Vol. 12, No. 1, pp.5578.

Kolvereid, L. (1997), Prediction of employment status choice intentions, Entrepreneurship Theory \&

Practice, 21, pp. 47-57.

Krueger, N.F.Jr. and Brazeal, D.V. (1994), Entrepreneurial Potential and Potential Entrepreneurs, Entrepreneurship Theory \&Practice, 18(3), 91-104.

Krueger, N. F. Jr., Reilly, M.D. and Carsrud, A. L. (2000) Competing Models of Entrepreneurial Intentions., Journal of Business Venturing, 15, 411432.

Lee D. and Tsang, E. (2001), The Effects of Entrepreneurial Personality, Background and Network Activities on Venture Growth, Journal of Management Studies, Vol. 38, No. 4, 583-602.

Morrison A., Breen, J. and Ali, S. (2003), Small Business Growth: Intention, Ability and Opportunity, Journal of Small Business Management, Vol. 41, No. 4, pp.417-425.

Papadaki, E.and Chami, B. (2002), Growth Determinants of Micro-Businesses in Canada". Research report presented at CEA 37th Annual Meetings Thursday,May 29-June 1,2003, http://strategis.ic.gc.ca/epic/internet/ insbrprppe.nsf/vwapj/growth_determinants.pdf/SFILE/gro wth_determinants pdf (12.03.2004)

Phan H. P., Wong, P.K. and Wang, C.K., (2002), Antecedents to Entrepreneurship among University Students in Singapore: Beliefs, Attitudes and Background, Journal of Enterprising Culture, Vol. 10, No: 2, 151-174

Poutziouris, P. (2003), The Strategic Orientation of Owner/Managers of Small Ventures, International Journal of Entrepreneurial Behaviour and Research, Vol. 9, No.5, pp. 185-214.

Reynolds, P.D. (1995), Who Starts New Firms? Linear Additive versus Interaction Based Models, 15th Babson College Entrepreneurship Research Conference, London, April 13-15

Sadler-Smith, E., Y. Hampson, I. Chaston and B. Badger. (2003), Managerial Behavior, Entrepreneurial Style and Small Firm Performance, Journal of Small Business Management, Vol. 41, No. 1, pp.47-67. 
Sandberg, W.R. and Hofer, C.W. (1987), Improving New Venture Performance: The Role of Strategy, Industry Structure, and the Entrepreneur, Journal of Business Venturing, Vol. 2, No. 1, 5-28.

Sarıaslan H. (2001), Avrasya ve Türkiye'de KOB_'lerin ekonomik kalkınmadaki yeri ve Önemi,. 1. Avrasya Küçük ve Orta Ölçekli_sletmeler Kongresi, Biskek, Kirgizistan, 27-35.

Storey, D.J. (1994), Understanding the Small Business Sector, London: Routledge.

Tkachev, A., and Kolvereid, L. (1999), Selfemployment intentions among Russian students, Entrepreneurship and Regional Development 11(3), pp.269-280.

Verheul I., Thruik R., and Grilo I (2005), Determinants of self-employment preference and realization of women and men in Europe and the United States, 2005, EIM Scales paper N200513, Zoetermeer: EIM Business and Policy Research

Wang, C. and Wong, P., (2004), Entrepreneurial Interest of University Students in Singapore, Technovation, 24, pp. 163-172.

Welter, F. (2001), Who Wants To Grow? Growth Intentions and Growth Profiles of (Nascent)

Entrepreneurs in Germany, In P. D. Reynolds, W. D. Bygrave, N. M. Carter, P. Davidsson, W. B. Gartner, C. M. Mason, \& P. P. Mcdougall (eds.). Frontiers of Entrepreneurship Research. Wellesley, Ma: Babson

College, 91-100. 